\title{
Botulinum toxin for the prevention and healing of wound scars: A systematic review of the literature
}

\author{
Anastasia Prodromidou MD, Maximos Frountzas MD, Dimitrios-Efthymios G Vlachos MD PhD, \\ Georgios D Vlachos MD PhD, Ioannis Bakoyiannis MSc, Despina Perrea PhD, Vasilios Pergialiotis MD MSc PhD
}

\begin{abstract}
A Prodromidou, M Frountzas, D-EG Vlachos, et al. Botulinum toxin for the prevention and healing of wound scars: A systematic review of the literature. Plast Surg 2015;23(4):260-264.
\end{abstract}

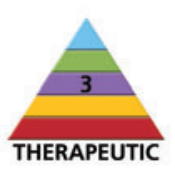

BACKGROUND: Botulinum toxin injections have been investigated for the treatment or prevention of hypertrophic scars in several clinical studies. However, its clinical effectiveness has not yet been established. OBJECTIVE: To examine all available evidence that support the use of botulinum toxin injections for the treatment or prevention of hypertrophic scars in current clinical practice.

METHODS: A systematic review searching the MEDLINE (1966 to 2014), Scopus (2004 to 2014), Popline (1974 to 2014), ClinicalTrials.gov (2008 to 2014) and Cochrane Central Register of Controlled Trials (CENTRAL) (1999 to 2014) databases together with reference lists from included studies was conducted.

RESULTS: Ten studies ( 255 patients) were included. Of these, 123 patients were injected with botulinum toxin type $\mathrm{A}$, nine patients were offered botulinum toxin type $\mathrm{B}$ and the remaining 123 patients represented the control groups. Significantly improved cosmetic outcomes were observed among certain studies using the visual analogue scale (experimental group: median score 8.25 [range 6 to 10]) versus control group: median score 6.38 [range 2 to 9]; $\mathrm{P}<0.001$ ) and the Stony Brook Scar Evaluation Scale (experimental group score: 6.7 versus control group score: $4.17 ; \mathrm{P}<0.001$ ) assessments. However, the methodological heterogeneity of the included studies, the lack of control group in the majority of them, the use of subjective scales of measurement and the frequent use of patient self-assessment precluded unbiased results.

CONCLUSIONS: Current evidence does not support the usage of botulinum toxin. Future randomized controlled trials are needed in the field to reach firm conclusions regarding its place in current clinical practice.

Key Words: Botulinum; Scar; Wound

Fery discontinuity of the skin can influence its architecture and Cleave a scar. The cosmetic outcome of surgical and wound scars is of great importance for both surgeons and patients. However, it appears that a large number of scars heal pathologically, resulting in hypertrophic scars (HS) or even keloids. It has been suggested that their pathogenesis is synergistic, involving topographical, metabolic, circulatory, immunological and nutritional factors combined with genetic predisposition (1). Mast cells, vascular endothelial growth factor and alterations in fibroblast concentration are suggested to be of great importance in the process of healing $(2,3)$. Many therapeutic and treatment strategies have been suggested to improve the aesthetic result of HS and keloids (4). Several alternative therapies have been suggested including corticosteroid injections, pressure on the scar, Asiatic acid applications or even radiation therapy (5). Recent studies strived to find novel strategies; electroporation combined with bleomycin has recently been suggested for resistant keloids as well as a combination of laser and triamcinolone injections $(6,7)$

Botulinum toxin injections are also considered by many studies to be an innovative and efficient therapy for HS and keloids. However, its clinical effectiveness has not yet been established. The purpose of

\section{La toxine botulique pour prévenir et guérir les cicatrices des plaies : une analyse bibliographique systématique}

HISTORIQUE : Plusieurs études cliniques ont porté sur la prévention et le traitement des cicatrices hypertrophiques grâce aux injections de toxine botulique, mais leur efficacité clinique n'a pas encore été démontrée. OBJECTIF : Examiner toutes les données probantes qui appuient l'utilisation d'injections de toxine botulique pour traiter ou prévenir les cicatrices hypertrophiques en pratique clinique.

MÉTHODOLOGIE : Les chercheurs ont réalisé une analyse systématique des bases de données MEDLINE (1966 à 2014), Scopus (2004 à 2014), Popline (1974 à 2014), ClinicalTrials.gov (2008 à 2014) et Cochrane Central Register of Controlled Trials (CENTRAL) (1999 de 2014) ainsi que des listes de références des études retenues.

RÉSULTATS : Les chercheurs ont retenu dix études, comptant un total de 255 patients. De ce nombre, 123 ont reçu une injection de toxine botulique de type $\mathrm{A}$, neuf se sont fait offrir de la toxine botulique de type $\mathrm{B}$ et les 123 autres faisaient partie des groupes témoins. D'après l'échelle visuelle analogique, certaines études donnaient des résultats beaucoup plus esthétiques (groupe expérimental : score médian de 8,25 [plage de six à dix]) que ceux du groupe témoin : score médian de 6,38 [plage de deux à neuf]; $\mathrm{P}<0,001)$ et l'échelle Stony Brook d'évaluation des cicatrices (score du groupe expérimental : 6,7 par rapport à celui du groupe témoin : $4,17 ; \mathrm{P}<0,001)$. Cependant, à cause de l'hétérogénéité méthodologique des études retenues, de l'absence de groupe témoin dans la majorité d'entre elles, de l'utilisation d'échelles de mesure subjectives et du recours fréquent à l'autoévaluation des patients, il était impossible d'éviter les résultats non biaisés.

CONCLUSIONS : Les données probantes actuelles n'appuient pas l'utilisation de toxine botulique. D'autres essais aléatoires et contrôlés s'imposent pour établir hors de tout doute si elle a sa place en pratique clinique.

our systematic review was to examine all available evidence that support its use in current clinical practice.

Study design

\section{METHODS}

The present study was designed according to the PRISMA guidelines (8). Eligibility criteria were predetermined by the authors. No language or date restrictions were applied during the literature search. All prospective and retrospective observational studies were deemed eligible for inclusion. Case reports were excluded. Two authors (AP and MF) abstracted and tabulated predetermined data to a structured form, while the rest of the authors reviewed them independently.

\section{Literature search and data collection}

MEDLINE (1966 to 2014), Scopus (2004 to 2014), Popline (1974 to 2014), ClinicalTrials.gov (2008 to 2014) and Cochrane Central Register of Controlled Trials (CENTRAL) (1999 to 2014) search engines were used in our primary search, together with reference lists from included studies. The search was restricted to a minimum number of key words to assess an eligible number that could be manually 
searched, minimizing the loss of articles. All articles that met or were presumed to meet the inclusion criteria were retrieved in full text. Search strategies and results are shown in Figure 1.

Medline was searched using the MeSH terms (botulinum[All Fields] AND ("wounds and injuries"[MeSH Terms] OR ("wounds"[All Fields] AND “injuries"[All Fields]) OR "wounds and injuries"[All Fields] OR "wound"[All Fields])) and using the search terms (botulinum[All Fields] AND ("cicatrix"[MeSH Terms] OR "cicatrix"[All Fields] OR "scar"[All Fields])). Scopus, Popline and CENTRAL were searched using terms "botulinum AND scar" and "botulinum AND wound". Clinical trials.org was searched using the term "botulinum".

\section{Definitions}

The Patient Scar Assessment Scale (PSAS), Observer Scar Assessment Scale (OSAS) (also known together as Patient and Observer Scar Assessment Scale [POSAS]), Vancouver Scar Scale (VSS), Visual Analogue Scale (VAS) and modified Stony Brook Scar Evaluation Scale (SBSES) are widely used scales of measurement that quantify the response to therapy concerning scar appearance. The VSS objectively evaluates four parameters of healing: vascularity, height/thickness, pliability and pigmentation. The PSAS and OSAS (POSAS) expands the included symptoms of pain and pruritus that are subjectively described on objective data captured in the VSS. The VAS measures pigmentation, vascularity, acceptability and observer comfort and contour by using photographs. The modified SBSES is a six-level scale that estimates short-term aesthetic results of wound healing by evaluating width, colour, height and visibility of the incision line. All these scales have been previously evaluated and seem to correlate well with the cosmetic VAS, with the exception of the PSAS, in which data are limited because it is mainly used as a component of the POSAS scale (9-12). However, the POSAS seems to be the most comprehensive because it takes in account both the patient's personal and the observer's objective perspectives (13).

The cosmetic result of wound healing after the application of botulinum toxin, as well as major and minor complications of its use, were the main outcome of our study.

\section{RESULTS}

Ten studies were included in the present systematic review (Table 1) (14-23). In total, 255 patients were enrolled. Of these, 123 patients experienced scar wounds or keloids and were injected with botulinum toxin type A (BTA). Nine patients were offered botulinum toxin type B. The remaining patients represented the control groups.

\section{Characteristics of included studies and potential bias}

Ziade et al (17) included 24 patients with facial wounds in a singleblind randomized controlled trial. Exclusion criteria included allergy to botulinum, known breastfeeding, myasthenia or previous injection of botulinum within a six-month interval. The 'toxin' group was injected with BTA and the 'control' group did not receive an injection. The injection was performed in the facial muscles involved in scar widening. They did not describe the process of randomization. The results were interpreted with PSAS, OSAS, VSS and VAS scales of measurement (17).

Gassner et al (22) included 31 patients who experienced forehead wounds (traumatic or after neoplastic excision) in their single-blind randomized controlled trial. Exclusion criteria were current pregnancy, breastfeeding, history of irradiation and or chemotherapy, hematological disorders, neuromotor disorders and keloid formation. Among the 31 patients, 16 received BTA treatment while the rest were given preservative-free normal saline. The injections were performed in the underlying musculature covering a diameter of approximately $1 \mathrm{~cm}$ to $3 \mathrm{~cm}$ around the scar's edges. The randomization was performed using blocks of random numbers. They did not describe the method of allocation concealment (22).

Xiao et al (20) included 19 patients who had a single hypertrophic lesion (any location) for more than two years in a prospective, uncontrolled observational trial. Lesion volumes ranged from $2.5 \mathrm{~cm}^{3}$ to

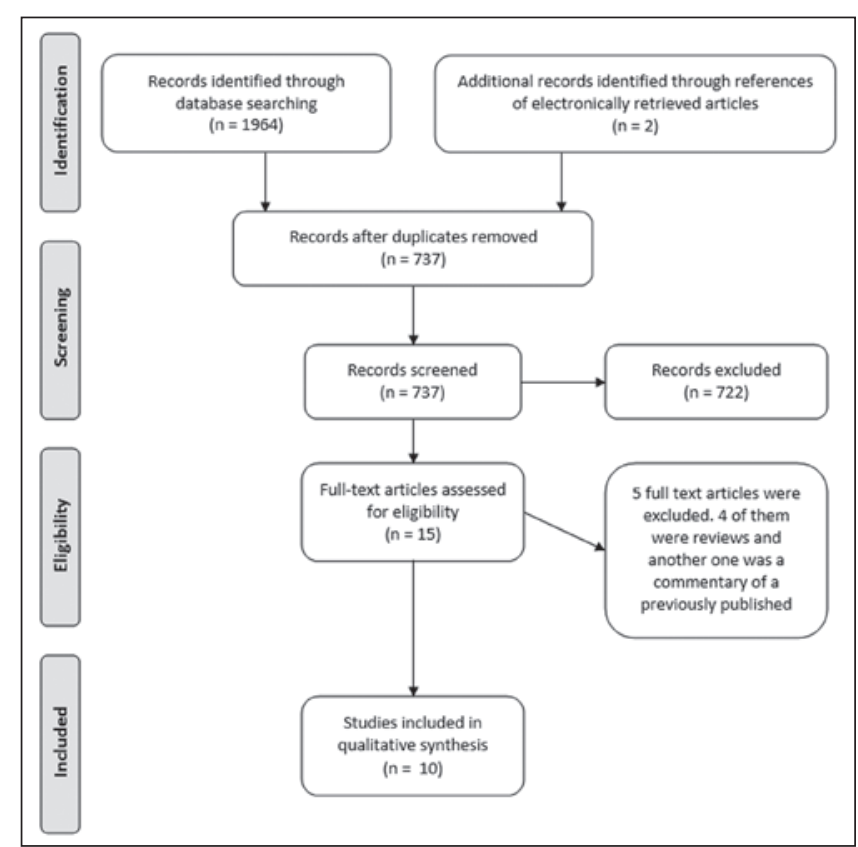

Figure 1) Search plot diagram

$35 \mathrm{~cm}^{3}$. Exclusion criteria included any kind of therapy during the previous year and during the time after the beginning of the therapy, current pregnancy, planned pregnancy, chronic renal failure, breast feeding, pathological liver and blood cell control. The wound was injected with BTA using a needle in three-monthly intervals. The dose of the toxin depended on the size of wound, but no more than $100 \mathrm{U}$ per treatment (20).

Kim et al (14) included 15 patients $>18$ years of age with a recent $(<10$ days) thyroidectomy neck scar with a mean length of $8 \mathrm{~cm}$ in a randomized, controlled split-scar study. Excluded were patients who were allergic to botulinum toxin, pregnant or lactating, suffering from myasthenia, injected with the toxin in the previous six months and those who refused to participate. Patients were injected with a 31-gauge, $8 \mathrm{~mm}$ needle with BTA (100 U) mixed with $0.9 \%$ saline on one-half of the scar and $0.9 \%$ saline on the other. The exact point of injection was not mentioned. The randomization was based on a generator setting the left or right side with number 0 or 1 . Both the patients and the dermatologist performing the injections were blinded, while the other examiners were absent from the injection room (14).

Wilson (23) included 40 patients with traumatic facial wounds undergoing scar revision surgery. The type of study was not available. Patients with traumatic scars in the forehead and the cheek, $3 \mathrm{~cm}$ to $18 \mathrm{~cm}$ in length, were included in the study, excluding those with scars of burn origin. Patients were injected with a mix of a crystallized BTA $100 \mathrm{U}$, sodium chloride $0.9 \mathrm{mg}$ and human albumin $0.5 \mathrm{mg}$ diluted with normal saline immediately following scar revision surgery; the injections were performed with an insulin syringe into the musculature around the wound in a diameter of approximately $3 \mathrm{~mm}$ to $4 \mathrm{~mm}$ around the edges (23).

Gauglitz et al (18) included four patients with keloids that had persisted for more than two years. The patients had not received other forms of treatment during the previous six months. The injections were performed inside the keloid scar in bimonthly intervals by using a 24-gauge needle and a dose of 70 to 140 Speywood units of BTA. The treatment lasted for a maximum of six months (18).

Robinson et al (16) included 12 patients with keloids located on the sternum, neck, thigh or cheek after burn injuries, skin surgery or idiopathic in nature. Neither the type of study nor the exclusion criteria were available. The BTA therapy lasted, on average, 11 months without reference to the exact point and time of the injection (16). 
TABLE 1

Methodological characteristics of studies and patient outcome after injection with botulinum toxin

\begin{tabular}{|c|c|c|c|c|c|c|c|c|c|}
\hline $\begin{array}{l}\text { Authors, } \\
\text { year } \\
\text { (reference) }\end{array}$ & Type of study & $\begin{array}{l}\text { Sample } \\
\text { size, } n\end{array}$ & $\begin{array}{l}\text { Inclusion } \\
\text { criteria }\end{array}$ & Age & $\begin{array}{l}\text { Time of } \\
\text { injection }\end{array}$ & $\begin{array}{l}\text { Therapy, } \\
\text { duration }\end{array}$ & Follow-up & Scale & Results \\
\hline $\begin{array}{l}\text { Kim et al, } \\
2014 \text { (14) }\end{array}$ & DB-RCT & 15 & $\begin{array}{l}>18 \text { years of age } \\
\text { with a thyroidec- } \\
\text { tomy (neck) scar } \\
\text { of }<10 \text { days }\end{array}$ & $\begin{array}{l}\text { Mean } 46 \\
\text { versus } 46 \\
\text { years }\end{array}$ & $\begin{array}{l}\text { Mean } 6.6 \text { days } \\
\text { postsurgery } \\
\text { (range 5-9 } \\
\text { days) }\end{array}$ & $\begin{array}{l}\text { BTA; single } \\
\text { injection }\end{array}$ & $\begin{array}{l}2 \text { weeks; } \\
1,3 \text { and } 6 \\
\text { months }\end{array}$ & SBSES & $\begin{array}{l}6.70 \pm 1.52 \text { vs } 4.17 \pm 1.44 \\
(P<0.001)\end{array}$ \\
\hline $\begin{array}{l}\text { Wilson, } 2013 \\
\text { (15) }\end{array}$ & N/A & 80 & $\begin{array}{l}\text { Persistent keloids } \\
\text { (1-4 years) }\end{array}$ & N/A & $\begin{array}{l}\text { Postoperative } \\
\text { day } 9 \\
\text { (5-FU was } \\
\text { also added to } \\
\text { the regimen) }\end{array}$ & $\begin{array}{l}\text { BTA; single } \\
\text { injection }\end{array}$ & $\begin{array}{l}17 \text { to } 24 \\
\text { months } \\
\text { (mean } \\
19.6 \text { months) }\end{array}$ & $\begin{array}{l}\text { Subjectively } \\
\text { estimated by } \\
\text { the patient } \\
\text { ) }\end{array}$ & $\begin{array}{l}67(83.75 \%) \text { patients rated } \\
\text { the improvement as } \\
\text { significant, } 10(12.5 \%) \text { as } \\
\text { slight and } 3(3.75 \%) \text { as } \\
\text { unchanged }\end{array}$ \\
\hline $\begin{array}{l}\text { Robinson, } \\
2013 \text { (16) }\end{array}$ & N/A & 12 & Keloid scars & $\begin{array}{l}\text { Mean } 30 \\
\text { years } \\
(9-47 \\
\text { years })\end{array}$ & N/A & $\begin{array}{l}\text { BTA; mean } \\
\text { (range) } 11 \\
(2-43) \text { months }\end{array}$ & N/A & VSS & $\begin{array}{l}\text { Complete flattening of the } \\
\text { keloid scar in an average of } \\
11 \text { months (range 2-43 } \\
\text { months) in } 9 \text { patients. } 2 \\
\text { patients developed recur- } \\
\text { rences adjacent to previ- } \\
\text { ously treated areas, } 1 \\
\text { developed ulceration due to } \\
\text { concurrent steroid therapy. } \\
1 \text { received intense pulsed } \\
\text { light therapy and developed } \\
\text { an ulcer leading to recur- } \\
\text { rence }\end{array}$ \\
\hline \multirow{4}{*}{$\begin{array}{l}\text { Ziade et al, } \\
2013(17)\end{array}$} & \multirow[t]{4}{*}{ SB-RCT } & \multirow[t]{4}{*}{24} & \multirow{4}{*}{$\begin{array}{l}>18 \text { years of age } \\
\text { with a facial } \\
\text { wound without } \\
\text { tissue loss }\end{array}$} & \multirow{4}{*}{$\begin{array}{l}\text { Mean } 37 \\
\text { versus } 41 \\
\text { years }\end{array}$} & \multirow{4}{*}{$\begin{array}{l}72 \mathrm{~h} \text { postsur- } \\
1 \text { gery }\end{array}$} & \multirow{4}{*}{$\begin{array}{l}\text { BTA; single } \\
\text { injection }\end{array}$} & \multirow{4}{*}{$\begin{array}{l}\text { 7th day and } \\
1 \text { st year }\end{array}$} & PSAS & $9(6-18)$ versus $8(6-26)$ \\
\hline & & & & & & & & OSAS & $8(6-13)$ versus $9(5-24)$ \\
\hline & & & & & & & & vss & $3(1-4)$ versus $2(1-9)$ \\
\hline & & & & & & & & VAS & $\begin{array}{l}8.25(6-10) \text { versus } 6.38 \\
(2-9)(P<0.001)\end{array}$ \\
\hline $\begin{array}{l}\text { Gauglitz et } \\
\text { al, } 2012 \\
(18)\end{array}$ & N/A & 4 & $\begin{array}{l}\text { Keloids resistant } \\
\text { to any previous } \\
\text { therapy for }>2 \\
\text { years }\end{array}$ & N/A & $\begin{array}{l}\text { At least } 6 \\
\text { months after } \\
\text { cessation of } \\
\text { any previous } \\
\text { treatment }\end{array}$ & $\begin{array}{l}\text { BTA, every } 2 \\
\text { months for a } \\
\text { maximum of } \\
6 \text { months }\end{array}$ & N/A & $\begin{array}{l}\text { Three- } \\
\text { dimensional } \\
\text { optical profiling } \\
\text { system }\end{array}$ & $\begin{array}{l}\text { No changes on the } \\
\text { macroscopic appearance, } \\
\text { morphology or size of } \\
\text { keloid scars }\end{array}$ \\
\hline \multirow[t]{4}{*}{$\begin{array}{l}\text { Xiao et al, } \\
2009(20)\end{array}$} & \multirow[t]{4}{*}{$\begin{array}{l}\text { Prospective, } \\
\text { uncontrolled } \\
\text { observational }\end{array}$} & \multirow[t]{4}{*}{19} & \multirow[t]{4}{*}{$\begin{array}{l}\text { Single hypertro- } \\
\text { phic lesion that } \\
\text { persisted for } \\
>2 \text { years }\end{array}$} & \multirow[t]{4}{*}{38.5} & \multirow[t]{4}{*}{$\begin{array}{l}\text { At least } 2 \text { years } \\
\text { after the } \\
\text { scar's } \\
\text { development }\end{array}$} & \multirow[t]{4}{*}{$\begin{array}{l}\text { BTA; once } \\
\text { monthly for a } \\
\text { total duration } \\
\text { of } 3 \text { months }\end{array}$} & \multirow[t]{4}{*}{ Half-year } & $\begin{array}{l}\text { Patient } \\
\text { assessed } \\
\text { Doctor } \\
\text { assessed }\end{array}$ & $\begin{array}{l}12 \text { good } \\
7 \text { excellent } \\
15 \text { good } \\
4 \text { excellent }\end{array}$ \\
\hline & & & & & & & & $\begin{array}{l}\text { Mean erythema } \\
\text { score }\end{array}$ & $3.41 \pm 1.23$ \\
\hline & & & & & & & & $\begin{array}{l}\text { Mean pliability } \\
\text { score }\end{array}$ & $3.85 \pm 0.78$ \\
\hline & & & & & & & & $\begin{array}{l}\text { Mean itching } \\
\text { score }\end{array}$ & $3.50 \pm 0.83$ \\
\hline $\begin{array}{l}\text { Zhibo and } \\
\text { Miaobo, } \\
2009 \text { (24) }\end{array}$ & $\begin{array}{l}\text { Prospective } \\
\text { uncontrolled } \\
\text { observational }\end{array}$ & 12 & $\begin{array}{l}\text { Keloids of any } \\
\text { duration }\end{array}$ & $\begin{array}{l}\text { Range } \\
16-45 \\
\text { years }\end{array}$ & $\begin{array}{l}\text { Discontinuation } \\
\text { of any previ- } \\
\text { ous treatment } \\
\text { at least } 3 \\
\text { months }\end{array}$ & $\begin{array}{l}\text { BTA; 3-month } \\
\text { intervals for } \\
\text { a maximum } \\
\text { of } 9 \text { months }\end{array}$ & 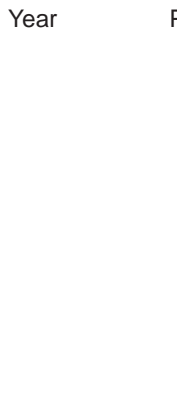 & $\begin{array}{l}\text { Patient satisfac- } \\
\text { tion, photo- } \\
\text { graphic record } \\
\text { and observa- } \\
\text { tions of an } \\
\text { independent } \\
\text { observer at } \\
\text { the beginning, } \\
\text { at } 1 \text { and } 3 \\
\text { months and } \\
\text { at yearly follow- } \\
\text { up }\end{array}$ & $\begin{array}{l}3 \text { patients excellent, } \\
5 \text { good, } \\
4 \text { fair } \\
\text { None of the patients } \\
\text { showed failure of therapy } \\
\text { Peripheral regression of } \\
\text { lesions was noted, in } \\
\text { addition to flattening in all } \\
\text { cases, and there was no } \\
\text { evidence of recurrence } \\
\text { after } 1 \text { year }\end{array}$ \\
\hline
\end{tabular}


TABLE 1 - CONTINUED

Methodological characteristics of studies and patient outcome after injection with botulinum toxin

\begin{tabular}{|c|c|c|c|c|c|c|c|c|c|}
\hline $\begin{array}{l}\text { Authors, } \\
\text { year } \\
\text { (reference) }\end{array}$ & Type of study & $\begin{array}{l}\text { Sample } \\
\text { size }\end{array}$ & $\begin{array}{l}\text { Inclusion } \\
\text { criteria }\end{array}$ & Age & $\begin{array}{l}\text { Time of } \\
\text { injection }\end{array}$ & $\begin{array}{l}\text { Therapy, } \\
\text { duration }\end{array}$ & Follow up & Scale & Results \\
\hline $\begin{array}{l}\text { Gassner et } \\
\text { al, } 2006 \\
(22)\end{array}$ & SB-RCT & 31 & $\begin{array}{l}>18 \text { years with } \\
\text { traumatic lacera- } \\
\text { tions or undergo- } \\
\text { ing excision of } \\
\text { cutaneous neo- } \\
\text { plasms }\end{array}$ & $\begin{array}{c}\text { Mean } \pm S D \\
62.0 \pm 18.2 \\
\text { versus } \\
60.2 \pm 16.7 \\
\text { years }\end{array}$ & $\begin{array}{l}\text { Within } 24 \mathrm{~h} \\
\text { after wound } \\
\text { closure }\end{array}$ & BTA, N/A & 6 months & $10 \mathrm{~cm}$ VAS & 8.9 versus $7.2(P=0.003)$ \\
\hline
\end{tabular}

BTA Botulinum toxin A; BTB Botulinum toxin B; DB-RCT Double-blind randomized controlled trial; FU Fluorouracil; N/A Not available; OSAS Observer Scar Assessment Scale; PSAS Patient Scar Assessment Scale; SB-RCT Single-blind randomized controlled trial; SBSES Stony Brook Scar Evaluation Scale; VAS Visual Analogue Scale; VSS Vancouver Scar Scale

Zhibo and Miaobo (24) included 12 patients with chest, shoulder and earlobe keloids in their prospective uncontrolled observational trial. Inclusion criteria included no keloid treatment of any kind in the previous three months. The exclusion criteria were not mentioned. Patients were injected with $70 \mathrm{U}$ to $140 \mathrm{U}$ of BTA per scar with a 24-gauge needle every three months for approximately nine months. The exact point of injection was not mentioned (24).

Wilson (15) included 80 patients with presternal, facial, trunk, earlobe and arm keloids present for a mean of 1.3 years. The type of study was not mentioned. The keloids were a result of surgical scars, trauma, puncture of the earlobe and infections of the skin. Exclusion criteria included duration of the keloid less than one year, lack of extension of the keloid and the existence of a keloid after a burn. Nine days after the surgical excision, the patients were injected once with $50 \mathrm{mg} / \mathrm{mL}$ of 5 -fluorouracil (together with $50 \mathrm{IU} / \mathrm{mL}$ of BTA) using a 30 -gauge needle. The injections were both intradermal and subdermal around the edges of the scar (15).

Flynn (19) included 18 patients who underwent Mohs micrographic surgery and reconstruction for nonmelanoma skin cancer or melanoma in situ in a retrospective uncontrolled observational trial. All lesions were located on the forehead and frontalis region, the nose, the chin, the glabella, the scalp and the zygoma. Nine patients received BTA and nine botulinum toxin B. They included patients with postsurgical scars that influenced the subjacent muscles and the movements of the skin. Exclusion criteria were not mentioned. The injection was performed in the underlying muscles $1 \mathrm{~cm}$ to $2 \mathrm{~cm}$ around the edges of the incision every $0.7 \mathrm{~cm}$ to $1.0 \mathrm{~cm}$. The dose of the toxin depended on the muscle group (19).

\section{Main outcomes}

An analysis of the included studies revealed the outcomes were heterogeneously reported. Specifically, some studies reported their results based on the patients' satisfaction (eg, PSAS), whereas others were based on independent observers (eg, OSAS or VSS) or on treating doctors (eg, VAS). Subjective score scales as well as photographic records were also used.

In two studies, VAS scores were significantly improved among patients who received BTA compared with controls (median score 8.25 [range 6 to 10] versus median score 6.38 [range 2 to 9]; $\mathrm{P}<0.001$ ), and ( 8.9 versus $7.2 ; \mathrm{P}=0.003)(17,22)$. However, this was not observed using other measurement scales (PSAS, OSAS, VSS). The VSS was also utilized by Robinson et al (16), who reported improvement in the appearance of the scar in all but four patients, who experienced recurrences. Similarly, the SBSES revealed a statistically significant difference between the two sides of the scar $(6.7$ versus 4.17 ; $<<0.001)$ in the Kim et al (14) split-scar study. Three studies suggest an improved cosmetic result based both on patients' subjective opinion and analysis of photographic records $(19,23,24)$. Xiao et al $(20)$ further strengthened their results using independent observers. The same researchers (21) also described a statistically significant reduction in erythema, pliability and itching scores $(\mathrm{P}<0.01)$. Wilson $(15)$ based their results on patient selfreport; in this study, the majority of patients $(83.75 \%)$ evaluated their outcomes as significantly improved (15). Gauglitz et al (18) found no change on the total appearance of the keloid when it was measured objectively with a three-dimensional profiling system.

Major complications related to botulinum injection such as ptosis of the upper lid, drooling, problems with mastication, muscle weakness and infection were not described. However, minor complications such as pruritus, burning sensation, pain, postinflammatory hyperpigmentation and mild headaches were noticed but were symptomatically treated and gradually subsided. Smile asymmetry was reported among certain patients with zygomatic scars $(17,23)$.

Complications related to wound healing were also present and involved recurrences of the HS or keloids (partial and complete), atrophy of the skin, ulceration, partial wound dehiscence, late widening and an epidermal slough. However, these were seldom observed, and affected a relatively small number of patients.

\section{DISCUSSION}

The beneficial effect of BTA in the treatment of keloids and surgical wounds remains to be established. To date, several studies have been conducted to investigate its effectiveness against keloids and surgical wounds, as well as its safety. However, it seems that the existing trials, which are included in our systematic review, suffer from obvious weaknesses such as the relatively small number of enrolled patients, the subjective assessment of cosmetic improvement and insufficient stratification.

The assumption that BTA is effective on the treatment of keloids and scars is supported by in vitro and experimental animal models. BTA delays fibroblast growth by inhibiting the cell cycle and, thereby, reduces HS development (25). In addition, BTA decreases the expression of connective tissue growth factor, which is a downstream regulator of the transforming growth factor- $\beta 1$ (TGF- $\beta 1$ ), and inhibits the growth of fibroblasts as well as the scar expansion (21). BTA reduces the concentration of TGF- $\beta 1$ in fibroblasts; in fact, the more BTA is given the most the concentration of TGF- $\beta 1$ is downscaled (20). Furthermore, BTA decreases the infiltration of inflammatory cells during wound healing, reduces fibrosis, but counterintuitively leads to extension of its length (26). Moreover, BTA causes muscular paralysis and reduces muscle closing tension during the healing of a wound, thereby improving the 
cosmetic outcome in rabbit ear postoperative scars (27). Finally, BTA inhibits collagen production and restricts wound hypertrophy in rabbit ear models as well as inhibiting fibroblasts cell cycle in vivo. The majority of fibroblasts that were not treated with BTA were mainly in the G2/M phase of the cell cycle compared with the treated ones, which were arrested in the G0/G1 phase (28).

\section{Strengths and weaknesses}

In the present systematic review, we aimed to include all the available studies in the international literature to clearly mark out all their data that support or refute the efficacy of BTA in healing keloids and scars. The main weakness of our systematic review relies on the low methodological quality of the included trials. The number of enrolled participants is relatively small and underpowered; furthermore, with the exception of three trials $(14,17,22)$, the majority were uncontrolled studies. A very significant disadvantage of these studies is that the assessment of the effect of BTA is mainly based on the patients' perception of wound healing (24), although some trials used objective scales such as the OSAS, the VSS and the VAS (17).

\section{Implications for future research}

The existing data are insufficient to reach firm conclusions regarding the therapeutic effect of BTA in keloids and scars. Therefore, further research is mandated. It is our belief that a more specific stratification should be applied based on the type of wound (eg, keloids versus HS).

\section{REFERENCES}

1. Huang C, Murphy GF, Akaishi S, Ogawa R. Keloids and hypertrophic scars: Update and future directions. Plast Reconstr Surg 2013;1:e25.

2. Chun Q, Zhiyong W, Fei S, Xiqiao W. Dynamic biological changes in fibroblasts during hypertrophic scar formation and regression. Int Wound J 2014. Epub ahead of print.

3. Gaber MA, Seliet IA, Ehsan NA, Megahed MA. Mast cells and angiogenesis in wound healing. Anal Quant Cytol Histol 2014;36:32-40.

4. Tziotzios C, Profyris C, Sterling J. Cutaneous scarring: Pathophysiology, molecular mechanisms, and scar reduction therapeutics. Part II. Strategies to reduce scar formation after dermatologic procedures. J Am Acad Dermatol 2012;66:13-24; quiz 5-6.

5. Boose JP, Papillon J, Frenette G. Clinical study of a new antikeloid agent. Ann Plast Surg 1979;3:13-21.

6. Manca G, Pandolfi P, Gregorelli C, Cadossi M, de Terlizzi F. Treatment of keloids and hypertrophic scars with bleomycin and electroporation. Plast Reconstr Surg 2013;132:621e-30e.

7. Sadeghinia A, Sadeghinia S. Comparison of the efficacy of intralesional triamcinolone acetonide and 5-fluorouracil tattooing for the treatment of keloids. Dermatol Surg 2012;38:104-9.

8. Liberati A, Altman DG, Tetzlaff J, et al. The PRISMA statement for reporting systematic reviews and meta-analyses of studies that evaluate healthcare interventions: Explanation and elaboration. BMJ 2009;339:b2700.

9. Singer AJ, Arora B, Dagum A, Valentine S, Hollander JE. Development and validation of a novel scar evaluation scale. Plast Reconstr Surg 2007;120:1892-7.

10. Lindeboom JA, Bruijnesteijn van Coppenraet ES, Kuijper EJ, et al. Interpretation and precision of the Observer Scar Assessment Scale improved by a revised scoring. J Clin Epidemiol 2008;61:1289-95.

11. Hoogewerf CJ, van Baar ME, Middelkoop E, van Loey NE. Patient reported facial scar assessment: Directions for the professional. Burns 2014;40:347-53.

12. Deslauriers V, Rouleau DM, Alami G, MacDermid JC. Translation of the Patient Scar Assessment Scale (PSAS) to French with crosscultural adaptation, reliability evaluation and validation. Can J Surg 2009;52:E259-63.

13. Vercelli S, Ferriero G, Sartorio F, Stissi V, Franchignoni F. How to assess postsurgical scars: A review of outcome measures. Disabil Rehabil 2009;31:2055-63.

14. Kim YS, Lee HJ, Cho SH, Lee JD, Kim HS. Early postoperative treatment of thyroidectomy scars using botulinum toxin: A split-scar,
We also believe that surgical and trauma wounds should be differentiated. In addition, stratification according to ethnicity and age is essential because these elements affect wound healing and should, therefore, be taken in account. Studies should also consistently evaluate the assessment of treatment based on objective scales such as OSAS, VSS and VAS, which should only be interpreted by trained staff, thus avoiding the introduction of assessment bias. Finally, future trials should use control groups and enroll an adequate number of patients to achieve statistical power.

\section{CONCLUSION}

The available evidence does not support the use of BTA for the treatment or the prevention of HS. Although the underlying pathophysiological mechanisms seem to suggest its beneficial action, this is not sufficiently demonstrated in clinical studies. The main flaws of existing clinical studies rely in their poor methodological quality, which subjects them to significant bias. Future randomized controlled trials are needed to reach firm conclusions regarding its use in current clinical practice.

DISCLOSURES: The authors have no financial disclosures or conflicts of interest ot declare.

double-blind randomized controlled trial. Wound Repair Regen 2014;22:605-12

15. Wilson AM. Eradication of keloids: Surgical excision followed by a single injection of intralesional 5 -fluorouracil and botulinum toxin. Can J Plast Surg 2013;21:87-91.

16. Robinson AJ, Khadim MF, Khan K. Keloid scars and treatment with Botulinum Toxin Type A: The Belfast experience. J Plast Reconstr Aesthet Surg 2013;66:439-40.

17. Ziade M, Domergue S, Batifol D, et al. Use of botulinum toxin type A to improve treatment of facial wounds: A prospective randomised study. J Plast Reconstr Aesthet Surg 2013;66:209-14.

18. Gauglitz GG, Bureik D, Dombrowski Y, Pavicic T, Ruzicka T, Schauber J. Botulinum toxin A for the treatment of keloids. Skin Pharmacol Physiol 2012;25:313-8.

19. Flynn TC. Use of intraoperative botulinum toxin in facial reconstruction. Dermatol Surg 2009;35:182-8.

20. Xiao Z, Zhang F, Cui Z. Treatment of hypertrophic scars with intralesional botulinum toxin type A injections: A preliminary report. Aesthetic Plast Surg 2009;33:409-12.

21. Xiao Z, Zhang M, Liu Y, Ren L. Botulinum toxin type A inhibits connective tissue growth factor expression in fibroblasts derived from hypertrophic scar. Aesthetic Plast Surg 2011;35:802-7.

22. Gassner HG, Brissett AE, Otley CC, et al. Botulinum toxin to improve facial wound healing: A prospective, blinded, placebocontrolled study. Mayo Clin Proc 2006;81:1023-8.

23. Wilson AM. Use of botulinum toxin type A to prevent widening of facial scars. Plast Reconstr Surg 2006;117:1758-66; discussion 67-8.

24. Zhibo X, Miaobo Z. Intralesional botulinum toxin type A injection as a new treatment measure for keloids. Plast Reconstr Surg 2009;124:275e-7e.

25. Zhibo X, Miaobo Z. Botulinum toxin type A affects cell cycle distribution of fibroblasts derived from hypertrophic scar. J Plast Reconstr Aesthet Surg 2008;61:1128-9.

26. Lee BJ, Jeong JH, Wang SG, Lee JC, Goh EK, Kim HW. Effect of botulinum toxin type a on a rat surgical wound model. Clin Exp Otorhinolaryngol 2009;2:20-7.

27. Gassner HG, Sherris DA, Otley CC. Treatment of facial wounds with botulinum toxin $\mathrm{A}$ improves cosmetic outcome in primates. Plast Reconstr Surg 2000;105:1948-53; discussion 54-5.

28. Wang L, Tai NZ, Fan ZH. [Effect of botulinum toxin type A injection on hypertrophic scar in rabbit ear model]. Zhonghua Zheng Xing Wai Ke Za Zhi 2009;25:284-7. 